\title{
DESAFIOS DO DIREITO INTERNACIONAL SANITÁRIO DURANTE A PANDEMIA DE COVID-19: PODER NORMATIVO, RETIRADA E FINANCIAMENTO DA ORGANIZAÇÃO MUNDIAL DA SAÚDE
}

PEDRO FARIAS OLIVEIRA ${ }^{1}$

RESUMO: O artigo examina, pontualmente, alguns desafios surgidos para o Direito Internacional Sanitário no contexto da pandemia de COVID-19. A partir da construção histórica de uma Governança Sanitária Global, o Direito Internacional transformou a Organização Mundial da Saúde (OMS) no ponto central de coordenação de estratégias de combate a pandemias. A organização, com status de agência especializada da Organização das Nações Unidas (ONU) é encarregada da difícil tarefa de atender aos anseios da sociedade internacional por uma resolução do problema. A tensão social e institucional resultou em um choque de visões acerca do poder normativo da OMS e de sua atuação durante a crise. Nesse contexto, o trabalho esclarece as espécies normativas produzidas pela OMS e demonstra o caráter não vinculante das recomendações temporárias, além de explicitar questões relativas à denúncia dos acordos constitutivos da organização e a seu financiamento, dentro de um quadro de ruptura com a regulação global sobre a matéria sanitária.

PAlavras-Chave: Direito Internacional Sanitário; Governança Sanitária Global; Organização Mundial da Saúde; Poder normativo; Denúncia; Financiamento.

\section{INTRODUÇÃO}

O ano de 2020 foi e ano de 2021 vem sendo, no mínimo, atípicos. A pandemia de COVID-19 implicou mudanças fundamentais no estilo de vida das pessoas ao redor do mundo, provocando alterações estruturais na organização de modelos de negócios, na prestação de serviços educacionais, na realização de eventos, nas formas de lazer etc. A sociedade, com certeza, não estava acostumada com a ideia de isolamento social, ou sequer preparada para ela. No campo jurídico, diversos desafios foram trazidos à atenção dos operadores do Direito, como a autonomia das entidades federativas para estabelecer regras de enfrentamento da pandemia, a existência de deveres fundamentais de proteção da saúde pública, a má utilização de recursos públicos em situações emergenciais e os efeitos do rompimento ou suspensão de relações jurídicas contratuais por razões alheias à vontade das partes.

\footnotetext{
${ }^{1}$ Professor Substituto de Direito Internacional Público na Faculdade de Direito da Universidade Federal do Rio de Janeiro. Mestre em Direito Internacional pela Universidade do Estado do Rio de Janeiro. Assessor jurídico no Ministério Público do Estado do Rio de Janeiro.
} 
Para o Direito Internacional, as discussões focaram-se na possibilidade de responsabilização da China pela disseminação da doença e, principalmente, no aparato normativo e burocrático da Organização Mundial da Saúde (OMS). Esse último aspecto, objeto do presente estudo, foi marcado por declarações de certos líderes mundiais, que acenderam um acalorado debate sobre a legitimidade e a obrigatoriedade das recomendações da organização, bem como sobre a destinação de recursos a ela enviados e a possibilidade de captura de seu processo decisório.

O presente artigo tem o objetivo de apresentar, portanto, o que se considera ser alguns dos principais desafios para o Direito Internacional Sanitário diante da pandemia. Para isso, no primeiro capítulo, faz-se uma introdução do tema, com a trajetória de desenvolvimento da governança sanitária global, em especial da construção da OMS. No segundo capítulo, aborda-se o poder normativo da organização, esclarecendo quais são as espécies normativas produzidas por seus órgãos, bem como seu grau de vinculatividade para os Estados membros. No terceiro capítulo, discutem-se as peculiaridades da ameaça mais incisiva à regulação global sanitária, que consiste na anunciada ruptura definitiva por parte de um de seus principais atores - os EUA -, tanto no aspecto material, isso é, o financiamento das atividades da OMS, quanto no aspecto jurídico-formal, ou seja, a denúncia do tratado constitutivo da organização. O presente trabalho também procura, no decorrer de seu texto, trazer aportes relevantes das teorias econômicas e das relações internacionais, notadamente o liberalismo institucional, considerando o contexto regulatório global.

\section{A CONSTRUÇÃo DE UMA GOVERNANÇA SANITÁRIA GLOBAL}

Conforme relata Menucci (2006, p. 58-60), há registro de propagação de epidemias desde, no mínimo, 431 a. C., quando Tucídides comentava a chegada da peste na Grécia, a primeira pandemia de que se tem notícia. A peste negra, por sua vez, assolou a Ásia e a Europa de meados do século XIV até 1665, atingindo cerca de $3 / 4$ da população europeia. Já nesse momento, vislumbrou-se a necessidade de medidas sanitárias que ultrapassassem as fronteiras de cada centro urbano, sendo as cidades-Estado italianas, amplos centros comerciais da época, pioneiras na adoção de tais providências, como a quarentena de embarcações estrangeiras. Várias outras pandemias ainda viriam, como a disseminação da peste em Hong Kong e na Índia, ao final do século XIX.

Até meados do mesmo século, contudo, ao lado do significativo desconhecimento científico sobre a transmissão de agentes patológicos que imperava na época, é certo que as tentativas concertadas de evitar a propagação de moléstias foram "mínimas e tomadas em nível local" (SOARES, 2000, p. 53). A República de Veneza (697-1797), por exemplo, entabulou tratados bilaterais com seus vizinhos no século XIV, prevendo medidas para o enfrentamento de "moléstias quarentenárias", isso é, 
aquelas que impunham a navios mercantes uns quarenta dias de obrigações de estar ao largo dos portos venezianos, bem como a criação de lazaretos (com finalidades de observação e tratamento de pessoas), sem que, com tais providências, se pudessem invocar restrições à liberdade de navegação pelos mares de então, ou ações unilaterais das autoridades públicas, em função da proteção de navios nacionais (SOARES, 2000, p. 53).

Foi a segunda pandemia de cólera, que assolou a América e a Europa entre 1830 e 1847, que motivou o início das tratativas multilaterais, com a realização da Primeira Conferência Sanitária Internacional, em Paris, no ano de 1851 (MENUCCI, 2006, p. 61). O encontro, convocado por Napoleão III, resultou na elaboração da primeira convenção sobre a matéria, que previa, inter alia, a proibição de fechamento de portos a um navio em razão da existência de uma doença epidêmica no país de origem. Tratava-se de preocupação de ordem humanitária e comercial, contra certas práticas draconianas que entravavam a navegação à época (VITTA, 1933, p. 564). A convenção também contava com um anexo que constituía verdadeiro ensaio de código sanitário, contendo uma descrição das moléstias quarentenárias e de alguns meios para evitar seu espraiamento. Além disso, foram consagrados alguns princípios basilares do Direito Sanitário, como

a obrigação de um Estado oficialmente declarar a existência de uma doença epidêmica em seu território (origem da declaração oficial de infecção), a obrigatoriedade de os navios estarem munidos de uma patente de saúde, limitações da duração de quarentenas, e a obrigação da indicação de um agente sanitário responsável em determinados portos marítimos (SOARES, 2000, p. 53-54).

O texto, assinado em 1852, todavia, não chegou a entrar em vigor, posto que ratificado por apenas três países, dois dos quais se retiraram do acordo alguns anos depois (VITTA, 1933, p. 565). Outras 13 conferências sanitárias foram realizadas até 1938, com destaque para a Conferência de Paris de 1903. Na oportunidade, ficou registrada a vontade dos Estados presentes de erigir um organismo sanitário internacional, e o estudo da viabilidade de sua criação foi delegado a uma comissão especial. Os frutos foram colhidos alguns anos mais tarde, em 09 de dezembro de 1907, quando foi fundado o Escritório Internacional de Higiene Pública (Office International d'Hygiène Publique, ou OIHP, na sigla em francês), por meio do então chamado Acordo de Roma.

A estrutura do Escritório era composta por um Comitê Permanente, integrado, por sua vez, por representantes técnicos dos Estados membros do Acordo. Ao Diretor-Geral e ao Secretário-Geral da organização cabiam a tarefa de auxiliar o Comitê e de intermediar a permuta de informações sobre saúde pública entre os membros, que era de extrema relevância no contexto das epidemias de peste, cólera e febre amarela. Todavia, a instituição não deixava de ser uma organização 
embrionária, com orçamento restrito e sem muito espaço de atuação direta em casos de emergências de saúde pública. Ainda assim, a área de operação do Escritório foi paulatinamente expandida, que deixou de se ocupar apenas de doenças quarentenárias e passou a tratar, igualmente, dos "campos da salubridade de gêneros alimentícios, da higiene ambiental e da construção e administração de hospitais" (SOARES, 2000, p. 55).

O fim da $1^{\text {a }}$ Guerra Mundial e a assinatura do Tratado de Versalhes marcaram o início de um novo período para o Direito Internacional. É o que apontam Accioly, Silva e Casella (2019, p. 63-71), aduzindo que, desde então, vive-se a época contemporânea do Direito das Gentes, a qual é marcada por diversos processos de reestruturação. $\mathrm{O}$ bilateralismo característico dos períodos anteriores deu lugar às negociações multilaterais, com foco no estabelecimento de fóruns de discussão internacional, rumo à institucionalização do sistema internacional. Além disso, o Direito Internacional deixou de se focar nos princípios de coexistência e de mútua abstenção, passando a se pautar, cada vez mais, pela cooperação, que se intensificaria principalmente após a $2^{\underline{a}}$ Guerra Mundial.

Nesse contexto, e diante dos gravíssimos problemas sanitários enfrentados pela Europa ao final da $1^{a}$ Guerra Mundial, foi criada, no seio da Sociedade das Nações $(\mathrm{SdN})$, a Organização Permanente de Higiene da $\mathrm{SdN}(\mathrm{OPH})$, que passou a coexistir com o Escritório Internacional de Higiene Pública. A intenção inicial, manifestada em uma Conferência Internacional de Higiene em 1920, era que a Organização absorvesse o Escritório; o que não foi possível em razão de não haver coincidência de membros nas entidades. Os EUA, por exemplo, recusavam-se a fazer parte da $\mathrm{SdN}$ e, consequentemente, de sua Organização Permanente de Higiene.

Mais tarde, em 1943, foi assinado o acordo constitutivo da UNRRA (United Nations Relief and Rehabilitation Administration), entidade de caráter transitório (SOARES, 2000, p. 63). Além de buscar solucionar os problemas de refugiados no pós-2 a Guerra Mundial, a UNRRA tinha a missão de assumir as funções da Organização Permanente de Higiene. Contudo, em 1945, por ocasião da Conferência de São Francisco, com base em uma proposta conjunta das delegações do Brasil e da China, foi aprovada uma recomendação de convocação de uma conferência diplomática com vistas ao estabelecimento de uma organização mundial de saúde (SHARP, 1947, p. 509). Além disso, também ficou consagrado na própria Carta da Organização das Nações Unidas (ONU) - adotada na mesma Conferência - que a organização deve favorecer "a solução dos problemas internacionais econômicos, sociais, sanitários e conexos" (artigo 55, "b", da Carta da ONU. Grifo nosso).

A pluralidade de organizações internacionais sanitárias globais $(\mathrm{OIHP}, \mathrm{OPH}$ e UNRRA) perdurou até 19 de junho de 1946, quando, ao final da Conferência Internacional da Saúde, foi assinada a Constituição da Organização Mundial da 
Saúde. ${ }^{2} \mathrm{O}$ tratado, originado de discussões travadas na própria ONU, no âmbito do Conselho Econômico e Social (ECOSOC), entrou em vigor em 07 de abril de 1948 e deu origem à OMS, organização com sede em Genebra que sucedeu, ao mesmo tempo, o Escritório Internacional de Higiene Pública, a Organização de Higiene da SdN e a UNRRA, herdando os direitos e os deveres de todas essas instituições.

Feito esse breve relato histórico, nota-se que o Direito Internacional Sanitário é um ramo do Direito Internacional Público que muito evoluiu desde que Cino Vitta, em curso da Haia ministrado em 1933, o conceituou como "um ramo do direito administrativo internacional" (VITTA, 1933, p. 549, tradução nossa), sendo este último formado pelas "relações que se dão entre Estados e entre outros sujeitos de direito internacional assimilados aos Estados (...) dentro do domínio da Administração Pública" (VITTA, 1933, p. 550, tradução nossa). Em obra de referência sobre o tema na doutrina brasileira, o Professor Guido Soares afirmou que as atuais normas sanitárias elaboradas sob a égide da Organização Mundial da Saúde, a exemplo do Regulamento Sanitário Internacional (RSI),

resultaram de uma experiência histórica acumulada, em particular, em congressos e conferências diplomáticas do século anterior, onde se nota uma progressiva mudança de enfoques políticodiplomáticos, para uma postura técnica, advinda da participação de órgãos governamentais, científicos ou universitários especializados em matéria de saúde pública e controles sanitários. Por outro lado, ainda que as regras técnicas internacionais assim adotadas não ganhassem um status de normas jurídicas internacionais, as discussões e eventuais recomendações, bem como a troca de experiências entre funcionários governamentais, já representariam importantes fatores para a disseminação de informações técnicas e científicas em matéria de controles de doenças, sobretudo em caso de epidemias, que os Estados, certamente, acabariam por incorporar na sua prática diuturna e adotar como normas de sua legislação sanitária interna (SOARES, 2000, p. 57).

Outros autores, como Mondielli (2007, p. 119-120), preferem utilizar o termo Direito Internacional da Saúde (DIS), o qual seria uma "parte do Direito Internacional Econômico e do Direito Internacional do Desenvolvimento". O DIS possuiria como objeto de estudo "as regras jurídicas aplicáveis pela comunidade internacional às ações de saúde, sendo que essas regras são principalmente produzidas pelas organizações internacionais e regionais". Além disso, seria possível verificar uma grande heterogeneidade normativa no ramo, a qual seria

\footnotetext{
${ }^{2} \mathrm{O}$ uso do termo "Constituição", apesar de simbólico, não acarreta qualquer consequência jurídica.

$\mathrm{O}$ instrumento tem natureza jurídica de tratado, não importando a designação utilizada, nos termos do artigo 1ํ, "a", in fine, da Convenção de Viena sobre Direito dos Tratados.
} 
coordenada, em nível internacional, pela OMS. Também seria um traço marcante do DIS sua forte institucionalização, com destaque para a necessidade de integração entre autoridades internacionais e nacionais, bem como de participação de atores não estatais, como Organizações Não Governamentais, e de outras organizações internacionais que acabam por também exercer competências de ordem sanitária (ex.: OIT, FAO, UNESCO etc.).

$\mathrm{Na}$ visão do autor do presente trabalho, essa trama complexa de características do Direito Internacional Sanitário (ou da Saúde) retrata a existência de uma governança sanitária global. ${ }^{3} \mathrm{O}$ fenômeno da governança global nada mais é do que uma "instância de governança na ausência de governo" (RUGGIE, 2014, p. 5). Uma vez que não há governo na ordem internacional, a regulação global fica a cargo de uma rede de normas provenientes de variadas fontes, com diferentes graus de vinculatividade e eficácia, que convergem para a consecução de objetivos comuns e para a solução de problemas que se estendem além das fronteiras de um Estado e que, portanto, requerem medidas internacionais de enfrentamento. As emergências de saúde pública inserem-se justamente no campo das questões essencialmente transfronteiriças, fazendo necessária a adoção de estratégias coordenadas de ação.

A institucionalização do sistema, em grande parte proporcionada pela estrutura da OMS, é fundamental para a construção de uma governança efetiva. Como asseveram Keohane e Martin (1995), expoentes do liberalismo institucional nas Relações Internacionais, as organizações internacionais podem fornecer informações, reduzir custos de transação, aumentar a credibilidade de compromissos assumidos por Estados e estabelecer pontos focais de coordenação. Além do mais, os fóruns de discussões consagrados pelas organizações internacionais permitem a redução de assimetria de informações e a elaboração de estratégias conjuntas de coordenação, evitando malefícios que, na teoria dos jogos, são típicos do famoso dilema dos prisioneiros. ${ }^{4}$ Ainda que os resultados esperados da mencionada alegoria não sejam sempre observáveis na prática - como relatam recentes estudos da economia comportamental (THALER, p. 144-145), os ganhos

\footnotetext{
${ }^{3} \mathrm{O}$ tema da governança global já foi tratado por este autor em obra anterior, todavia sob a perspectiva do Direito Internacional Ambiental (OLIVEIRA, 2017).

${ }^{4}$ Segundo sua formulação original, o dilema dos prisioneiros consiste no seguinte exemplo: dois criminosos foram presos e estão sendo interrogados separadamente, sendo certo que as provas de que dispõe o acusador são suficientes para condenar cada um a apenas um ano de prisão. Todavia, aos presos é dada a oportunidade de confessar ou de permanecer calado. Se ambos confessarem, serão sentenciados a cinco anos de prisão; se apenas um deles confessar, este poderá ser solto, enquanto o outro, que permaneceu calado, será preso por 10 anos. A lição extraída é que, quando os prisioneiros não possuem informações sobre o que o outro acusado fará ou sobre as provas que estão em mãos do acusador, sempre optarão por confessar, porque essa escolha maximizaria seu próprio interesse. A adoção dessa estratégia por ambos, entretanto, resulta em uma situação pior do que a inicial, visto que, se nada fizessem e permanecessem calados, seriam condenados a apenas um ano de prisão. Agora, com a confissão, os dois passarão cinco anos detidos.
} 
absolutos trazidos pela transparência e possibilidade de coordenação estratégica, especialmente em áreas técnicas e humanitárias, são incontestáveis.

\subsection{A OMS}

O preâmbulo da Constituição da $\mathrm{OMS}^{5}$ deixa claro que a organização possui status de agência especializada da ONU, ou "entidade especializada", nos moldes do termo utilizado nos artigos 57 a 59 da Carta da ONU. Isso significa dizer que ela é uma organização internacional distinta das Nações Unidas, com personalidade jurídica e orçamentos próprios, porém vinculada à ONU mormente por uma circunstância de fato: "os Estados-membros são praticamente os mesmos, e não há inconveniente em que, reunidos no foro principal, que é a ONU, ali estabeleçam diretrizes de ação" (REZEK, 2018, p. 212). Ainda assim, alguns suaves vínculos jurídicos são verificáveis: (i) a Assembleia Geral da Organização das Nações Unidas (AGONU) pode fazer recomendações não vinculantes às agências especializadas sobre questões orçamentárias (artigo 17, (3), da Carta da ONU); e (ii) as agências especializadas atuam em estreita cooperação com os demais órgãos da ONU, podendo, por exemplo, solicitar pareceres consultivos à CIJ quando devidamente autorizadas pela AGONU (artigo 96, (2), da Carta da ONU).

O objetivo da OMS é bastante ambicioso, consistindo na "aquisição, por todos os povos, do nível de saúde mais elevado que for possível" (artigo $1^{\underline{0}}$ da Constituição da OMS). Para atingi-lo, a instituição deve desempenhar as funções inscritas no extenso rol do artigo $2^{\underline{0}}$ da Constituição, in verbis:

\section{Capítulo II - Funções}

Artigo 2. Para conseguir o seu objetivo, as funções da Organização serão:

a) Atuar como autoridade diretoria e coordenadora dos trabalhos internacionais no domínio da saúde;

b) Estabelecer e manter colaboração efetiva com as Nações Unidas, organismos especializados, administrações sanitárias governamentais, grupos profissionais e outras organizações que se julgue apropriado;

c) Auxiliar os Governos, a seu pedido, a melhorar os serviços de saúde;

d) Fornecer a assistência técnica apropriada e, em caso de urgência, a ajuda necessária, a pedido dos Governos ou com o seu consentimento;

\footnotetext{
5 "Aceitando estes princípios com o fim de cooperar entre si e com os outros para promover e proteger a saúde de todos os povos, as partes contratantes concordam com a presente Constituição e estabelecem a Organização Mundial da Saúde como um organismo especializado, nos termos do artigo 57 da Carta das Nações Unidas."
} 
e) Prestar ou ajudar a prestar, a pedido das Nações Unidas, serviços sanitários e facilidades a grupos especiais, tais como populações de territórios sob tutela;

f) Estabelecer e manter os serviços administrativos e técnicos julgados necessários, compreendendo os serviços de epidemiologia e de estatística;

g) Estimular e aperfeiçoar os trabalhos para eliminar doenças epidêmicas, endêmicas e outras;

h) Promover, em cooperação com outros organismos especializados, quando for necessário, a prevenção de danos por acidente;

i) Promover, em cooperação com outros organismos especializados, quando for necessário, o melhoramento da alimentação, da habitação, do saneamento, do recreio, das condições econômicas e de trabalho e de outros fatores de higiene do meio ambiente;

j) Promover a cooperação entre os grupos científicos e profissionais que contribuem para o progresso da saúde;

k) Propor convenções, acordos e regulamentos e fazer recomendações respeitantes a assuntos internacionais de saúde e desempenhar as funções que neles sejam atribuídas à Organização, quando compatíveis com os seus fins;

1) Promover a saúde e o bem-estar da mãe e da criança e favorecer a aptidão para viver harmoniosamente num meio variável;

m) Favorecer todas as atividades no campo da saúde mental, especialmente as que afetam a harmonia das relações humanas;

n) Promover e orientar a investigação no domínio da saúde;

o) Promover o melhoramento das normas de ensino e de formação prática do pessoal sanitário, médico e de profissões afins;

p) Estudar e relatar, em cooperação com outros organismos especializados, quando for necessário, as técnicas administrativas e sociais referentes à saúde pública e aos cuidados médicos sob os pontos de vista preventivo e curativo, incluindo os serviços hospitalares e a segurança social;

q) Fornecer informações, pareceres e assistência no domínio da saúde;

r) Ajudar a formar entre todos os povos uma opinião pública esclarecida sobre assuntos de saúde;

s) Estabelecer e rever, conforme for necessário, a nomenclatura internacional das doenças, das causas de morte e dos métodos de saúde pública;

t) Estabelecer normas para métodos de diagnóstico, conforme for necessário; 
u) Desenvolver, estabelecer e promover normas internacionais com respeito aos alimentos, aos produtos biológicos, farmacêuticos e semelhantes;

v) Dum modo geral, tomar as medidas necessárias para alcançar os fins da Organização.

Em relação à sua estrutura, a OMS não apresenta construção muito diferente do padrão observado na maioria das organizações internacionais contemporâneas, sendo integrada pela Assembleia Mundial da Saúde (AMS), pelo Conselho Executivo e pelo Secretariado. A AMS, composta por delegados que representam os Estados membros (artigo 10 da Constituição da OMS), é o órgão deliberativo supremo da organização. Ela reúne-se anualmente (artigo 13) para decidir sobre os temas inseridos em suas funções. ${ }^{6} \mathrm{O}$ Conselho Executivo, por sua vez, é um órgão de propensão executiva, encarregando-se, entre outras atribuições, ${ }^{7}$ de assegurar o

${ }^{6}$ Artigo 18. As funções da Assembléia da Saúde serão:

a) Determinar a política da Organização;

b) Indicar os Estados membros com direito a designar uma pessoa para fazer parte do Conselho;

c) Nomear o diretor-geral;

d) Rever e aprovar os relatórios e as atividade do Conselho e do diretor-geral, dar ao Conselho instruções em relação com os assuntos sobre os quais possam considerar-se convenientes medidas, estudos, investigações ou elaboração de relatórios;

e) Criar as comissões que considere necessárias às atividades da Organização;

f) Fiscalizar a política financeira da Organização e rever e aprovar o orçamento;

g) Dar instruções ao Conselho e ao diretor-geral para chamar a atenção dos Estados membros e das organizações internacionais, governamentais ou não governamentais, sobre qualquer assunto respeitante à saúde que a Assembléia considere apropriado;

h) Convidar qualquer organização internacional ou nacional, governamental ou não governamental, que tenha responsabilidades relacionadas com as da Organização, a nomear representantes para participar, sem direito de voto, nas suas sessões ou nas das comissões e conferências reunidas sob a sua autoridade, nas condições prescritas pela Assembléia da Saúde; mas, no caso de organizações nacionais, os convites só serão enviados com o consentimento do Governo interessado;

i) Considerar recomendações que tratem de saúde, feitas pela Assembléia Geral, pelo Conselho Econômico e Social, pelo Conselho de Segurança ou pelo Conselho de Tutela das Nações Unidas e informá-los das medidas tomadas pela Organização para levar a efeito tais recomendações;

j) Relatar ao Conselho Econômico e Social, em conformidade com as disposições de qualquer acordo realizado entre a Organização e as Nações Unidas;

k) Promover e dirigir investigações no domínio da saúde pelo pessoal da Organização, pelo estabelecimento das suas próprias instituições ou pela cooperação com instituições oficiais ou não oficiais de qualquer Estado membro, com o consentimento do respectivo Governo;

1) Criar quaisquer outras instituições que considere convenientes;

m) Tomar quaisquer outras medidas tendentes a realizar o objetivo da Organização.

${ }^{7}$ Artigo 28. As funções do Conselho serão:

a) Executar as decisões e as diretrizes da Assembléia da Saúde;

b) Atuar como órgão executivo da Assembléia da Saúde;

c) Exercer todas as funções que lhe sejam confiadas pela Assembléia da Saúde; 
cumprimento das decisões da AMS. Por fim, o Secretariado é o órgão administrativo da organização, responsável pelas operações do cotidiano burocrático. É chefiado pelo Diretor-Geral, autoridade máxima do aparato da OMS, cujas responsabilidades incluem, mas não se limitam a nomear o pessoal do Secretariado (artigo 35 da Constituição da OMS) e preparar e apresentar anualmente ao Conselho os relatórios financeiros e as previsões orçamentais da organização (artigo 36 da Constituição da OMS). Atualmente, o Diretor-Geral é o Sr. Tedros Adhanom, cujo mandato de cinco anos se iniciou em 1ํㅡㄹ de julho de 2017.

A OMS possui, ainda, a particularidade de ser, na forma dos artigos 44 e 45 de sua Constituição, uma organização essencialmente descentralizada, dispondo de órgãos regionais que não deixam de ser parte integrante da instituição. A regionalização é essencial para a consecução dos objetivos da OMS, uma vez que os serviços sanitários internacionais devem "refletir as necessidades e as realidades regionais" (SOARES, 2000, p. 75). Ademais, a divisão também se justifica no fato de que, no momento de criação da OMS, já existiam diversas organizações regionais, a exemplo da Organização Panamericana de Saúde.

\section{O PODER NORMATIVO DA OMS}

Durante o período da pandemia de COVID-19, foram - e continuam sendo frequentes as menções às "recomendações da OMS", que deveriam ser "seguidas" (ou não) por líderes nacionais, instituições internacionais e entidades internas. Nesse contexto, faz-se necessário esclarecer a natureza jurídica dessas previsões, bem como seus efeitos e a possibilidade de vinculação para os países membros da organização.

Inicialmente, cumpre assentar que o poder normativo da OMS decorre do artigo $2^{2}$, " $\mathrm{k}$ ", de sua Constituição, que insere, dentre as funções da organização, o poder para "propor convenções, acordos e regulamentos e fazer recomendações respeitantes a assuntos internacionais de saúde e desempenhar as funções que neles sejam atribuídas à Organização, quando compatíveis com os seus fins". Dentro dessa função, as normas produzidas pela OMS variam conforme o grau de vinculação dos Estados membros e a origem do texto normativo.

d) Aconselhar a Assembléia da Saúde sobre as questões que lhe sejam apresentadas por aquele organismo e sobre os assuntos atribuídos à Organização por convenções, acordos e regulamentos;

e) Submeter pareceres ou propostas à Assembléia da Saúde, por sua própria iniciativa;

f) Preparar as ordens do dia das sessões da Assembléia da Saúde;

g) Apresentar à Assembléia da Saúde, para exame e aprovação, um programa geral de trabalho referido a um período determinado;

h) Estudar todos os assuntos dependentes da sua competência;

i) Tomar medidas de urgência dentro das funções e recursos financeiros da Organização para tratar de acontecimentos que exijam ação imediata.

Em particular pode autorizar o diretor-geral a tomar as medidas necessárias para combater as epidemias, participar no empreendimento de socorros sanitários a levar às vítimas de uma catástrofe e realizar estudos ou investigações sobre a urgência dos quais tenha sido chamada a atenção do Conselho por qualquer Estado membro ou pelo diretor-geral. 
Em um primeiro grupo, aquele das normas adotadas pela AMS, estão as Convenções, os Regulamentos e as Recomendações. As primeiras (Convenções) estão previstas no artigo 19 da Constituição da OMS, que confere autoridade à AMS para "adotar convenções ou acordos respeitantes a qualquer assunto que seja da competência da Organização". Elas devem ser aprovadas pela maioria de no mínimo dois terços dos votos da AMS, entrando em vigor para cada Estado Membro quando internalizados "em conformidade com as suas normas constitucionais". Exemplo de resultado desse processo legislativo internacional é a Convenção-Quadro para o Controle do Tabaco (CQCT), que foi promulgada, no Brasil, pelo Decreto n. ${ }^{\circ}$ 5.658/2006.

Ainda no grupo de normativas adotadas pela AMS estão os Regulamentos, que são medidas editadas com o respaldo do artigo 21 da Constituição da OMS, que assegura à AMS o poder para adotar instrumentos normativos concernentes a:

a) Medidas sanitárias e de quarentena e outros procedimentos destinados a evitar a propagação internacional de doenças;

b) Nomenclaturas relativas a doenças, causas de morte e medidas de saúde pública;

c) Normas respeitantes aos métodos de diagnóstico para uso internacional;

d) Normas relativas à inocuidade, pureza e ação dos produtos biológicos, farmacêuticos e similares que se encontram no comércio internacional;

e) Publicidade e rotulagem de produtos biológicos, farmacêuticos e similares que se encontram no comércio internacional.

Consoante o disposto no artigo 22, tais Regulamentos entram em vigor automaticamente para os Estados membros após a devida notificação de sua adoção pela AMS. Os países que não desejarem ser vinculados ao Regulamento aprovado devem manifestar sua rejeição (ou apor reservas, caso não concordem apenas com dispositivos específicos do texto), em verdadeiro exercício de direito de opt-out. Trata-se de algo extremamente raro no Direito Internacional: o nascimento de obrigações internacionais para Estados, ainda que ausente manifestação expressa de seu consentimento. Relevante para o presente contexto é o Regulamento Sanitário Internacional (RSI, ou International Health Regulations, no termo em inglês), cuja primeira versão foi adotada em $1969 .{ }^{8}$ A última - e única revisão deu-se em 2005 e, até o momento, nenhum Estado objetou suas disposições. O Brasil promulgou o texto do RSI, já revisado, por meio do Decreto n.. 10.212/2020, dando-lhe vigência interna, além da vigência internacional que já lhe conferiam, ao

\footnotetext{
${ }^{8}$ Em 1951, a OMS já tinha adotado regulamento similar, intitulado, em inglês, International Sanitary Regulations. A mudança de nome leva grande parte dos especialistas a não mencionar o diploma.
} 
menos desde 2007, a parte final do artigo 22 da Constituição da OMS e o artigo 59 do próprio Regulamento. ${ }^{9}$

A autoridade normativa da OMS, contudo, é geralmente utilizada para a edição de regras não vinculantes (soft law). Como asseveram Gostin, Sridhar e Hougendoubler $(2015$, p. 2), a organização raramente exerce sua potência coercitiva (hard power) por meio da negociação de diplomas internacionais vinculantes (Convenções e Regulamentos), ou seja, capazes de atrair a responsabilidade internacional do Estado por descumprimento. Nesse contexto, finalizando o grupo de normativas adotadas pela AMS, dispõe o artigo 23 da Constituição da OMS que o órgão tem "autoridade para fazer recomendações aos Estados membros com respeito a qualquer assunto dentro da competência da Organização". Também é prevista no artigo 62 a entrega de um relatório anual por cada Estado membro, que deve indicar "as medidas tomadas em relação às recomendações que lhe tenham sido feitas pela Organização e em relação às convenções, acordos e regulamentos". À luz do já mencionado artigo 23 da Constituição da OMS, a AMS já expediu importantes peças recomendatórias, como o Código Internacional de Marketing de Substitutos do Leite Materno (1981) e o Código de Prática de Recrutamento Internacional de Profissionais de Saúde (2010).

Outras formas de criação de soft law também existem no seio da organização. A OMS lida com temas técnicos complexos e, em consequência disso, desenvolveu uma série de estratégias para reunir e disseminar conhecimento e boas práticas sanitárias. Uma delas - já em um segundo grupo, bem mais numeroso, de normas

9 Artigo 59. Entrada em vigor; período para rejeição ou reservas

1. O período previsto em cumprimento do Artigo 22 da Constituição da OMS para a rejeição ou apresentação de reservas a este Regulamento, ou a uma de suas emendas, será de 18 meses a partir da data da notificação pelo Diretor-Geral quanto à adoção deste Regulamento ou de uma emenda a este Regulamento feita pela Assembleia da Saúde. Qualquer rejeição ou reserva recebida pelo Diretor-Geral após o término desse período não terá nenhum efeito.

2. Este Regulamento entrará em vigor 24 meses após a data de notificação referida no parágrafo $1^{\text {o }}$ deste Artigo, com exceção de:

(a) um Estado que tiver rejeitado este Regulamento ou uma de suas emendas, em conformidade com o Artigo 61;

(b) um Estado que tiver feito uma reserva, caso em que este Regulamento entrará em vigor conforme o disposto no Artigo 62;

(c) um Estado que vier a se tornar membro da OMS após a data da notificação pelo Diretor-Geral referida no parágrafo $1^{\circ}$ deste Artigo, e que ainda não seja signatário deste Regulamento, caso em que este Regulamento entrará em vigor conforme o disposto no Artigo 60; e

(d) um Estado não-membro da OMS que aceite este Regulamento, caso em que o mesmo entrará em vigor em conformidade com o parágrafo $1^{\circ}$ do Artigo 64.

3. Se algum Estado não for capaz de ajustar totalmente sua legislação nacional e regulamentos administrativos internos e este Regulamento no período estabelecido no parágrafo $2^{\mathrm{o}}$ deste Artigo, esse Estado apresentará, no período especificado no parágrafo $1^{\circ}$ deste Artigo, uma declaração ao Diretor-Geral referente aos ajustes ainda pendentes, que deverá completar num período de no máximo até 12 meses após a entrada em vigor deste Regulamento para aquele Estado Parte. 
não produzidas pela AMS - advém da criação de Comitês pelo Secretariado da organização, que informam suas descobertas e recomendações sem o endosso formal dos Estados membros (GOSTIN; SRIDHAR; HOUGENDOUBLER, 2015, p. 2). Trata-se, aqui, de diretrizes técnicas, bem como de publicações de estatísticas da saúde e de relatórios sobre temas que recaiam sobre o escopo de atuação da organização. Além disso, a OMS também estabeleceu uma rede de colaboradores significativamente extensa, a exemplo da GOARN (Global Outbreak Alert and Response Network), que trabalha no monitoramento e resposta a potenciais epidemias.

Em síntese, pode-se dizer que a OMS produz as seguintes espécies normativas: (a) tratados e convenções (artigo 19 da Constituição da OMS), adotados pela maioria de no mínimo dois terços dos votos da AMS, que são juridicamente vinculantes para os Estados contratantes, possuindo status inequívoco de tratado, nos termos do artigo 1ํㅡ. "a", da Convenção de Viena sobre Direito dos Tratados (CVDT); (b) regulamentos (artigos 21 e 22 da Constituição da OMS), adotados pela maioria simples dos votos da AMS, automaticamente vinculantes para os Estados membros, salvo expressa manifestação em contrário; (c) recomendações (artigo 23 da Constituição da OMS), igualmente adotadas pela maioria simples dos votos da AMS, porém não vinculantes para os Estados membros; e (d) demais regras provenientes do Secretariado, que não possuem previsão formal e direta na Constituição da OMS e que, apesar da relevância técnica, não geram obrigações para os Estados membros.

\subsection{As recomendações da OMS para o combate à pandemia de Covid-19}

As ditas "recomendações da OMS", tão frequentemente mencionadas durante o período da pandemia de COVID-19, não se inserem diretamente nas espécies acima elencadas. Não possuem fundamento direto na Constituição da OMS, mas sim em norma específica do RSI. Cabe, portanto, uma análise mais detida do mencionado diploma.

Como já visto, o RSI constitui um Regulamento adotado pela AMS nos termos dos artigos 21 e 22 da Constituição da OMS. No entanto, há certa controvérsia quanto à sua natureza jurídica. Apesar de poder ser classificado como um instrumento vinculante, por força da clareza do artigo 22 da Constituição da OMS, parte da doutrina questiona seu enquadramento na definição de tratado (SPAGNOLO, 2017, p. 3). Os principais argumentos contrários a dito enquadramento são a possibilidade de ausência de manifestação de vontade expressa dos Estados vinculados e o fato de que os regulamentos emanariam de um organismo internacional, constituindo decisões de organizações internacionais, classicamente diferenciadas dos tratados. Não é por outra razão que diversos autores, conquanto não neguem o caráter vinculante das disposições do RSI, caracterizam-no como espécie normativa sui generis (CHAZOURNES, 2007; VIRZO, 2015, p. 311-313; SPAGNOLO, 2017, p. 3). Digno de nota é, ainda, o entendimento de Roberto Ago (1958, p. 28), segundo o qual os regulamentos da 
OMS seriam acordos em forma simplificada, justamente por dispensar a etapa de ratificação. ${ }^{10}$ Além disso, convém lembrar que, tendo em vista a adoção por simples votação da AMS e o caráter vinculante dos regulamentos, a natureza destes parece próxima à das resoluções do Conselho de Segurança da ONU (CSONU), que também são, em regra, obrigatórias para os membros da organização, nos termos do artigo 25 da Carta da ONU. As resoluções do CSONU, contudo, já foram distinguidas de tratados pela Corte Internacional de Justiça (CIJ), eis que "emitidas por um único e coletivo órgão" e "negociadas mediante um processo muito diferente daquele utilizado para a conclusão de um tratado", de forma que "o texto final dessas resoluções representa a visão do Conselho de Segurança enquanto órgão" (CIJ, 2010, p. 43), e não de um Estado contratante.

A despeito dos entendimentos acima, na opinião deste autor - a qual encontra eco em Mazzuoli (2020b) e Schermers e Blokkers (2018, p. 824-825) -, a natureza jurídica do RSI é própria de um tratado. Isso porque o diploma se encaixa no conceito posto pelo artigo 2, (1), "a", da CVDT, segundo o qual um tratado é todo "acordo internacional concluído por escrito entre Estados e regido pelo Direito Internacional, quer conste de um instrumento único, quer de dois ou mais instrumentos conexos, qualquer que seja sua denominação específica". O fato de o consentimento estatal não se dar por escrito, mas por inércia do ente, não infirma essa conclusão, uma vez que a vontade do Estado em contrair a obrigação é inferida, nesse caso, de uma omissão. Relevante pontuar que, nos termos do artigo 11 da CVDT, "o consentimento de um Estado em obrigar-se por um tratado pode manifestar-se pela assinatura, troca dos instrumentos constitutivos do tratado, ratificação, aceitação, aprovação ou adesão, ou por quaisquer outros meios, se assim acordado" (grifo nosso). Ora, havendo os Estados, no momento da elaboração da Constituição da OMS, concordado em se obrigar aos regulamentos por mera inação, há de se respeitar a própria vontade dos membros, fazendo surgir efeitos jurídicos a partir do momento da expiração do prazo para opt-out.

Ademais, há diferenças em relação às resoluções adotadas pelo CSONU. A uma, em todo seu texto, o RSI dirige-se aos "Estados Partes", e não aos Estados Membros. A duas, ele também prevê um procedimento de adesão para Estados não membros da OMS (artigo 64), configurando verdadeiro processo de opt-in, na forma clássica da adesão internacional, mediante manifestação de vontade expressa. A três, o RSI é registrado perante o Secretário Geral da ONU (artigo 66, (3)), nos moldes preconizados pelo artigo 102, (1), da Carta da ONU. Todas essas características

10 “(...) os tratados em forma simplificada (conhecidos por executive agreements) são aqueles em que, para a sua conclusão, existe apenas uma única fase, consistente na assinatura do acordo, momento em que as partes já apõem o seu consentimento definitivo em obrigar-se pelo pactuado. Daí serem também chamados de acordos de procedimento abreviado (ou breve). Prescindem, em sua generalidade, de ratificação e, consequentemente, da intervenção formal do Parlamento. Muitos deles, pela sua simplicidade, sequer contam com a participação direta do Chefe de Estado, ficando a cargo de funcionários do governo ou, mais frequentemente, do Ministro das Relações Exteriores." (MAZZUOLI, 2014, p. 79). 
aproximam muito mais o RSI de um tratado do que de uma simples decisão de organização internacional.

Consignada a natureza jurídica do RSI, é de se pontuar que Mazzuoli (2020b) advogou, em recente artigo, a caracterização de responsabilidade internacional da China pelo descumprimento do dever de informar inscrito nos artigos $6^{0}$ e $7^{\circ}$ do referido diploma. Mais precisamente, segundo o autor, a China teria demorado mais de 24 horas para informar a OMS sobre evento que poderia constituir uma Emergência de Saúde Pública de Importância Internacional (ESPII, ou PHEIC, na sigla em inglês), ${ }^{11}$ ferindo frontalmente o artigo $6^{\circ}$. Além disso, também teria omitido informações relevantes a respeito do evento, violando o subsequente artigo 7o. Tendo isso em vista, o supracitado jurista sustenta que seria possível levar o caso à CIJ, com base no artigo 75 da Constituição da OMS, ${ }^{12}$ cuja validade já teria sido confirmada pela Corte no caso dos Conflitos Armados no Território do Congo, em julgamento de 2006. ${ }^{13}$

Escapa ao objeto deste estudo determinar se a China descumpriu ou não o RSI. Todavia, a aplicação do artigo 75 da Constituição da OMS ao descumprimento de um regulamento não parece de todo acertada. A tese pressupõe que a violação de uma norma do RSI também constituiria uma ofensa aos artigos 21 e 22 da Constituição da OMS, aspecto com o qual não se concorda. Os artigos mencionados apenas disciplinam: (i) as hipóteses em que a organização pode editar regulamentos; e (ii) o momento de entrada em vigor de tais diplomas internacionais. Dessarte, na opinião do autor do presente trabalho, a cláusula de submissão à jurisdição da CIJ contida no artigo 75 da Constituição da OMS não se aplica a eventuais descumprimentos do RSI, mas tão somente a divergências quanto à interpretação e à aplicação da própria Constituição. Com efeito, essa é outra interpretação possível assinalada por Almeida (2020).

Dito isso, e em que pese tudo que foi narrado até aqui, é certo que a maioria das referências a "recomendações da OMS" no tempo de pandemia ainda não foram abordadas. Isso porque, na maioria das vezes, as alusões eram feitas tendo em

\footnotetext{
${ }^{11}$ A ESPII é definida pelo artigo 1ํ, (1), do RSI como um “evento extraordinário que, nos termos do presente Regulamento, é determinado como: (i) constituindo um risco para a saúde pública para outros Estados, devido à propagação internacional de doença e (ii) potencialmente exigindo uma resposta internacional coordenada".

${ }_{12}$ Artigo 75. Qualquer questão ou divergência referente à interpretação ou aplicação desta Constituição que não for resolvida por negociações ou pela Assembléia da Saúde será submetida ao Tribunal Internacional de Justiça, em conformidade com o Estatuto deste Tribunal, a menos que as partes interessadas concordem num outro modo de solução.

13 "A Corte observa que a República Democrática do Congo é parte da Constituição da OMS desde 24 de fevereiro de 1961, e Ruanda desde 7 de novembro de 1962, e que tanto uma como a outra são membros dessa Organização. A Corte observa, igualmente, que o artigo 75 da Constituição da OMS prevê, sob as condições previstas nessa disposição, a competência da Corte para conhecer de "qualquer questão ou divergência referente à interpretação ou aplicação" deste instrumento. Essa disposição exige que tal questão ou divergência diga respeito à interpretação ou aplicação desta Constituição em particular" (CIJ, 2006, p. 41, tradução livre).
} 
mente outras espécies normativas provenientes da organização, previstas diretamente no RSI na hipótese de configuração de uma ESPII.

No contexto da COVID-19, em atenção ao artigo $6^{0}$ do RSI, a primeira comunicação sobre um evento que poderia constituir uma ESPII foi veiculada pela China em 31 de dezembro de 2019. ${ }^{14}$ Em seguida, em meio a outras comunicações, ${ }^{15}$ o Diretor-Geral deu início à avaliação para determinar se os eventos reportados constituiriam uma ESPII, autoridade que lhe é conferida pelo artigo 12, (1), do RSI. O Regulamento determina, igualmente, que o Diretor-Geral pode estabelecer um Comitê de Emergências, a fim de, mediante o fornecimento de pareceres, auxiliá-lo na mencionada tarefa, além de providenciar propostas de emissão, modificação, prorrogação ou extinção de recomendações temporárias (artigo 48, (1), "a" e "c", RSI). Assim é que foi instituído o Comitê de Emergências para a COVID-19, cuja primeira reunião se deu nos dias 22 e 23 de janeiro de 2020. Ao final do encontro, o Comitê e o Diretor-Geral consideraram ser muito cedo para declarar a ESPII, mas reconheceram, todavia, a necessidade de nova reunião em 10 dias. ${ }^{16}$

Na segunda reunião, em 30 de janeiro de 2020, ${ }^{17}$ o Comitê chegou à conclusão de que a situação atendia aos critérios de determinação de ESPII, o que enfim foi declarado pelo Diretor-Geral. Além disso, o Diretor acatou e emitiu recomendações temporárias formuladas pelo Comitê à China e a todos os demais países da sociedade internacional, no uso da atribuição que lhe é concedida pelo artigo 15 do RSI. ${ }^{18}$ São justamente essas recomendações, bem como outras transmitidas no

14 Disponível em: https://www.who.int/csr/don/05-january-2020-pneumonia-of-unkown-causechina/en/. Acesso em: 05 set. 2020.

15 Tailândia, em 13 de janeiro de 2020; Japão, em 16 de janeiro de 2020; e Coreia do Sul, em 20 de janeiro de 2020.

${ }^{16}$ Declaração disponível em: https://www.who.int/news-room/detail/23-01-2020-statement-on-themeeting-of-the-international-health-regulations-(2005)-emergency-committee-regarding-theoutbreak-of-novel-coronavirus-(2019-ncov). Acesso em 05/09/2020.

${ }_{17}$ Declaração disponível em: https://www.who.int/news-room/detail/30-01-2020-statement-on-thesecond-meeting-of-the-international-health-regulations-(2005)-emergency-committee-regardingthe-outbreak-of-novel-coronavirus-(2019-ncov). Acesso em: 05 set. 2020.

${ }_{18}$ Artigo 15 Recomendações temporárias

1. Caso se determinar, em conformidade com o Artigo 12, a ocorrência de uma emergência de saúde pública de importância internacional, o Diretor-Geral publicará recomendações temporárias, segundo o procedimento estabelecido no Artigo 49. Tais recomendações temporárias poderão ser modificadas ou prorrogadas, segundo as circunstâncias, mesmo depois de ter sido determinado o término da emergência de saúde pública de importância internacional, ocasião em que outras recomendações temporárias poderão ser emitidas, conforme as necessidades, a fim de evitar ou detectar prontamente sua recorrência.

2. As recomendações temporárias poderão incluir medidas de saúde que deverão ser implementadas pelo Estado Parte vivenciando a emergência em saúde pública de importância internacional, ou por outros Estados Partes, em relação a pessoas, bagagens, cargas, contêineres, meios de transporte, mercadorias e/ou encomendas postais, a fim de evitar ou reduzir a propagação internacional de doenças e evitar interferências desnecessárias com o tráfego internacional. 
decorrer do período da ESPII, ${ }^{19}$ que foram e continuam sendo o foco da mídia e de acaloradas discussões, pois incluem polêmicas medidas de enfrentamento do vírus, como o distanciamento social, a proibição de viajar, o uso de máscaras, o isolamento e tratamento de indivíduos infectados, a constante higiene das mãos e até mesmo a quarentena e o fechamento de meios de transporte e de estabelecimentos comercias.

Até o fechamento do texto deste artigo, o Comitê de Emergências para a COVID-19 ainda havia se reunido mais duas vezes, nas datas de $1^{\underline{0}}$ de maio de $2020^{20}$ e $1^{\text {o }}$ de agosto de $2020 .{ }^{21}$ Em ambas as oportunidades, a declaração de ESPII foi mantida, e novas recomendações temporárias foram emitidas, em razão do processo de revisão inscrito no artigo 15, (3), RSI, que prevê a expiração automática das recomendações após três meses. Além disso, em 11 de março de 2020, ${ }^{22}$ o Diretor-Geral da OMS declarou, em pronunciamento à mídia, que a COVID-19 alcançara o status de pandemia. Em que pese a gravidade de tal fato, a constatação não acarreta quaisquer consequências jurídicas sob os auspícios do RSI.

Mas seriam essas famigeradas recomendações do Comitê de Emergências para a COVID-19 obrigatórias para os Estados membros da OMS? Mazzuoli (2020a) sustenta que sim, citando os artigos 2o " "k", 23 e 62 da Constituição da OMS. Discorda-se desse entendimento, com respaldo na doutrina especializada (FIDLER; GOSTIN, 2006, p. 90; SPAGNOLO, 2017, p. 4). Como visto acima, as recomendações temporárias não possuem fundamento direto na Constituição da OMS, de modo que não são adotadas pela AMS, mas sim determinadas pelo Diretor-Geral, no uso da atribuição conferida pelo artigo 15, (1), do Regulamento. Ademais, o artigo 1, (1), do próprio RSI, define as recomendações temporárias como "uma orientação de natureza não-vinculante emitida pela OMS consoante o Artigo 15, para aplicação por tempo limitado, baseada num risco específico, em resposta a uma emergência de saúde pública de importância internacional, visando prevenir ou reduzir a propagação internacional de doenças e minimizar a interferência com o

3. As recomendações temporárias podem ser rescindidas a qualquer momento, de acordo com o procedimento estabelecido no Artigo 49, e expirarão automaticamente três meses após sua publicação. Podem ser modificadas ou prorrogadas por períodos adicionais de até três meses. As recomendações temporárias não podem estender-se além da segunda Assembleia Mundial de Saúde subsequente à determinação da emergência em saúde pública de importância internacional à qual se referem.

19 Vide lista completa em: https://www.who.int/emergencies/diseases/novel-coronavirus2019/technical-guidance-publications?publicationtypes=01bc799c-b461-4a52-8c7d-294c84cd7b2d. Acesso em: 05 set. 2020.

${ }^{20}$ Declaração disponível em: https://www.who.int/news-room/detail/01-05-2020-statement-on-thethird-meeting-of-the-international-health-regulations-(2005)-emergency-committee-regardingthe-outbreak-of-coronavirus-disease-(covid-19). Acesso em 05 set. 2020.

${ }^{21}$ Declaração disponível em: https://www.who.int/news-room/detail/01-08-2020-statement-on-thefourth-meeting-of-the-international-health-regulations-(2005)-emergency-committee-regardingthe-outbreak-of-coronavirus-disease-(covid-19). Acesso em 05 set. 2020.

22 Declaração disponível em: https://www.who.int/dg/speeches/detail/who-director-general-sopening-remarks-at-the-media-briefing-on-covid-19---11-march-2020. Acesso em: 05 set. 2020. 
tráfego internacional" (grifo nosso). Pretender a obrigatoriedade de tais protocolos é, portanto, ir de encontro à própria interpretação do termo assentada pelo tratado, bem como ignorar a vontade dos Estados no momento de sua elaboração. Poderia significar, inclusive, o abandono completo da normativa internacional, sob a alegação de desrespeito à soberania e ao domínio reservado dos Estados. ${ }^{23}$ Contudo, é inegável que, ainda que carentes de vinculatividade, as recomendações da OMS possuem grande peso técnico-científico, sendo, não raro, razão para adoção de postura deferente pelo Judiciário brasileiro. ${ }^{24}$ Demais disso, constituem blocos de conhecimento que elevam o ônus argumentativo da Administração na adoção de medidas contrárias no contexto do enfrentamento da ESPII, com fulcro no critério técnico exigido pelo artigo $3^{\circ}$, $\S 1^{\circ}$, da Lei n. ${ }^{\circ} 13.979 / 2020 .{ }^{25}$

A não obrigatoriedade, ao menos do ponto de vista do Direito Internacional, das recomendações da OMS resulta na impossibilidade de exercício de coerção contra os países que deixam de segui-las. Sendo assim, em determinados momentos, um quadro de ruptura é, apesar de indesejável, inevitável. Nas palavras de Fortes (2020, p. 231), a "ruptura consiste no ato de romper, isto é, em uma quebra de continuidade (PERRONE, 2016), o que pode importar em rompimento na estrutura da rede regulatória, pela recusa na adoção dos standards normativos por algum dos atores relevantes". No contexto da pandemia de COVID-19, o processo evidenciou-se pela atitude de determinados atores internacionais que se recusaram a aplicar as medidas de enfrentamento recomendadas pela OMS, rompendo, até certo ponto, com a cooperação internacional na matéria e com a governança global coordenada pela organização. O quadro ainda pode se aprofundar, uma vez que o momento de tensão institucional e humanitária motivou os EUA, principal financiador da OMS e um dos maiores players da ordem internacional, a anunciar

23 Com efeito, o Direito Internacional ainda é uma ordem normativa largamente baseada no consenso dos Estados. Eventuais interpretações dissonantes dessa vontade não raro resultam na dissolução de acordos internacionais. Mais do que isso, "o direito internacional é a mais honesta das especialidades do direito. O direito internacional, pelas próprias limitações estruturais aperfeiçoadas, mas persistentes, não se sente confortável lançando mão de escapes teóricos para justificar o injustificável - como frequentemente o direito interno testemunha na elasticidade insustentável de construções teóricas ou princípios que nada mais fazem do que justificar realidades políticas" (VASCONCELOS, 2018, p. 290).

24 Souza (2020) cita, por exemplo, as decisões acerca da proscrição do uso de amianto (ADI 4066), do prognóstico de doenças (Tribunal Regional Federal da 5áa Região. 1aㅜ Turma, Apelação Cível no . 581655), de identidade de gênero e alteração do registro civil independentemente de cirurgia (RE 670422) e da proibição de equipamentos de bronzeamento artificial (Tribunal Regional Federal da $3^{\text {a }}$ Região. 4 ${ }^{\mathrm{a}}$ Turma. Apelação Cível nº. 0008253-87.2011.4.03.6105).

${ }^{25}$ A Lei n. ${ }^{0}$ 13.979/2020 dispõe sobre as medidas para enfrentamento da emergência de saúde pública de importância internacional decorrente do coronavírus responsável pelo surto de 2019. Seu artigo $3^{\circ}$, $\S 1^{\mathfrak{o}}$, consagra que as medidas de enfrentamento da emergência de saúde pública de importância internacional "somente poderão ser determinadas com base em evidências científicas e em análises sobre as informações estratégicas em saúde e deverão ser limitadas no tempo e no espaço ao mínimo indispensável à promoção e à preservação da saúde pública". 
o congelamento das contribuições ao organismo (EUA, 2020) e, em seguida, sua saída da organização internacional $(G 1,2020)$.

\section{A POSTURA dOS EUA: DENÚNCIA E SUSPENSÃO DE CONTRIBUIÇÕES}

Concretizando os riscos de ruptura, em 07 de julho de 2020, o então Presidente dos EUA, Donald Trump, anunciou ao Congresso e às Nações Unidas que iniciou o processo de retirada de seu país da OMS (G1, 2020). A decisão já havia sido aventada em pronunciamento do líder em abril de 2020 (EUA, 2020), ocasião em que se sinalizou uma suspensão do envio de verbas para a organização. A declaração de julho, contudo, inseriu um termo inicial para a desvinculação definitiva dos norte-americanos: 06 de julho de 2021.

O processo de retirada de um país de um tratado é viabilizado por meio do instituto jurídico da denúncia, que consiste, mais precisamente, na declaração unilateral de um Estado com vistas a cessar sua participação no diploma internacional. Seus efeitos e trâmite geralmente vêm dispostos no próprio instrumento convencional. A Constituição da OMS, contudo, não prevê a denúncia em seu texto, o que atrai a aplicação das normas gerais de Direito dos Tratados, inscritas na CVDT de 1969. ${ }^{26}$

Os EUA, apesar de terem assinado a CVDT em 24 de abril de 1970, não chegaram a ratificar o texto, motivo pelo qual não são parte da convenção (ONU, 2020a). ${ }^{27}$ Assim, em uma primeira análise, seus termos não seriam vinculantes para o Estado norte-americano. Ocorre que, conforme assinalado pela doutrina, a CVDT reflete as normas costumeiras de Direito Internacional sobre o Direito dos Tratados e, estas sim, vinculam o Estado norte-americano, pois constituem parte do Direito Internacional Geral.

\footnotetext{
${ }^{26}$ No Brasil, a CVDT foi promulgada pelo Decreto n.․․ 7.030/2009, de onde se retiram as referências ao referido diploma internacional no presente trabalho.

${ }^{27} \mathrm{O}$ pedido de ratificação chegou a ser encaminhado ao Senado norte-americano pelo então presidente Richard M. Nixon em 1971. As discussões no órgão legislativo, contudo, chegaram a um impasse: o termo "tratado" na CVDT seria amplo demais para os Estados Unidos. O artigo 2, (1), (a), da Convenção, conceitua tratado como qualquer "acordo internacional concluído por escrito entre Estados e regido pelo Direito Internacional, quer conste de um instrumento único, quer de dois ou mais instrumentos conexos, qualquer que seja sua denominação específica". Desprezam-se, ainda, outros significados que "lhes possam ser dados na legislação interna do Estado" (artigo 2, (2)). Tal formulação, portanto, englobaria tanto a definição do termo "tratado" (treaty), constante da Constituição Americana (artigo 2, seção 2), quanto do termo "acordos executivos" (executive agreements), referendados pela jurisprudência do país. Na prática interna dos EUA, os acordos executivos não necessitam de aprovação congressual, sendo entabulados unicamente pelo Presidente. Com esse problema em vista, o Senado propôs uma declaração interpretativa, que reputava como não vinculantes os "tratados" que não contassem com a aprovação congressual. A declaração foi objetada pelo Departamento de Estado, em razão do temor de que os demais Estados membros passassem a entender que os EUA haviam abandonado a prática dos acordos executivos ou que não estariam verdadeiramente dispostos a cumpri-los (DALTON et al., 1984, p. 276-277). Nenhuma solução para a questão foi aceita desde então.
} 
O costume, fonte de grande relevância no Direito Internacional, é comumente formulado pela convergência de dois elementos: (i) uma prática reiterada dos Estados (inveterata consuetudo); e (ii) uma consciência da obrigatoriedade jurídica dessa prática, como aceitação de que constitui conduta prescrita pelo Direito (opinio juris sive necessitatis). ${ }^{28}$ Não há dúvidas que ambos os elementos estão presentes quando se analisa a prática americana, sendo muito frequentes as menções de órgãos estadunidenses internos aos preceitos da CVDT, para justificar sua conduta em questões relativas ao tema (DALTON et al., 278-279).

Firmadas essas premissas, o primeiro problema que se deve analisar é o artigo 56 da CVDT. Seu parágrafo primeiro estabelece uma presunção relativa (rebuttable presumption) de que os tratados que não contenham disposições relativas à sua extinção ou à retirada unilateral não são suscetíveis de denúncia. ${ }^{29}$ As hipóteses de refutação da presunção estão determinadas nas alíneas do mesmo parágrafo, e consistem nas seguintes circunstâncias: (i) quando se prove terem as partes tencionado admitir a possibilidade de denúncia; ou (ii) quando um direito de renúncia possa ser deduzido da natureza do tratado.

A Constituição da OMS não possui disposições acerca de sua extinção ou de denúncia de seu texto, de sorte que, a princípio, é aplicável o acima mencionado artigo 56. Nesse cenário, o que salvava a pretensão de retirada dos norteamericanos era a declaração ${ }^{30}$ feita pelo país no momento de ratificação do acordo, por meio de uma resolução conjunta do Congresso dos EUA, aprovada em 14 de junho de 1948. A referida resolução reservou ao Estado norte-americano o direito de retirada, mediante notificação com um ano de antecedência e quitação das obrigações financeiras para com a organização:

O Congresso adota essa resolução conjunta com o entendimento de que, na ausência de qualquer previsão na Constituição da Organização Mundial da Saúde sobre retirada da organização, os Estados Unidos se reservam o direito de retirada da organização mediante notificação de um ano de antecedência, desde que, no entanto, as obrigações financeiras dos Estados Unidos para com a organização sejam integralmente cumpridas no ano fiscal corrente da organização. (ONU, 2020b, tradução nossa).

\footnotetext{
${ }^{28}$ Nos termos do artigo 38 do Estatuto da Corte Internacional de Justiça, o costume é definido "como prova de uma prática geral aceita como sendo o direito".

${ }^{29}$ Os termos denúncia e retirada são sinônimos para a saída de um Estado de um tratado multilateral, hipótese na qual o diploma subsiste, permanecendo em vigor para os demais Estadosparte que não se retiraram.

${ }^{30} \mathrm{Na}$ opinião deste autor, a declaração em questão tem natureza jurídica de reserva. Apesar de não terem buscado "excluir ou modificar o efeito jurídico" (artigo 2, (1), "d", CVDT) de disposição expressa da Constituição da OMS, os EUA excepcionaram a regra geral inscrita no artigo 56 da CVDT e igualmente contida no silêncio eloquente do tratado.
} 
A ratificação da Constituição da OMS pelos EUA, interpretada de acordo com os termos acima transcritos, foi reconhecida como válida em 2 de julho de 1948, por meio de resolução da AMS, adotada de forma unânime (ONU, 2020b). Consagrouse, portanto, nessa oportunidade, a aquiescência dos membros da organização com a o direito de denúncia norte-americano. Dessa forma, conclui-se que, curiosa e coincidentemente, os EUA são o único Estado com um direito incontestável de retirada da OMS. Todos os outros membros deveriam, a princípio, comprovar uma das hipóteses previstas nas alíneas "a" e "b" do artigo 56, (1), da CVDT.

Daí se depreende, também, o motivo de a desvinculação dos EUA ter sido programada para 06 de julho de 2021. Uma vez que a notificação de saída foi enviada ao Secretário-Geral da ONU em 06 julho de 2020 (ONU, 2020c), ${ }^{31}$ somente após um ano - nos termos da declaração interpretativa feita pelo país e da regra costumeira reconhecida no artigo 56, (2), da CVDT - é que a retirada dos Estados Unidos pode produzir seus efeitos. Restaria saber apenas se a suspensão de envio de verbas sinalizada por Trump significaria um obstáculo à retirada, uma vez que a própria manifestação dos EUA previa o cumprimento integral das obrigações financeiras no "ano fiscal corrente" como requisito para a denúncia. ${ }^{32}$

Seja como for, fato é que, em 2021, os EUA voltaram atrás em sua decisão de deixar a OMS. Após a derrota sofrida nas eleições de 2020, Donald Trump deixou o cargo de Presidente, em conturbada transição de governo. Seu sucessor, Joe Biden, em um de seus primeiros atos como POTUS, reverteu a escolha tomada pela administração anterior e assegurou que os norte-americanos continuarão fazendo parte da OMS (G1, 2021). Desse modo, a ruptura acabou não se concretizando por questões de política interna, o que não torna, todavia, menos relevante a análise das possíveis consequências da decisão tomada pelo governo dos EUA em 2020, as quais serão objeto do capítulo a seguir.

\section{4..1 Aspectos orçamentários}

O financiamento da OMS é tratado no Capítulo XII (Orçamentos e Despesas) de seu acordo constitutivo, contemplando os artigos 55 a 58. Segundo os artigos 55 e 56, a aprovação do orçamento da organização é competência da AMS, após submissão, pelo Conselho Executivo, das previsões apresentadas pelo DiretorGeral. Ainda de acordo com o artigo 56, uma vez aprovadas as previsões orçamentárias, a AMS deve dividir proporcionalmente as despesas entre os Estados membros, de acordo com tabela fixada pelo mesmo órgão. Essas são as chamas

\footnotetext{
${ }^{31}$ O Secretário-Geral da ONU, na condição de depositário da Constituição da OMS, é o órgão ao qual se deve enviar a notificação de denúncia, nos termos da prática internacional e do artigo 77, (1), "c", da CVDT. O depositário, em seguida, deve informar as demais partes acerca do conteúdo da notificação (artigo 77, (1), "e", CVDT).

32 Em verdade, hoje, a OMS não possui um "ano fiscal", mas biênios, na forma da emenda à Constituição da OMS aprovada pela Resolução WHA26.37 da AMS em 22 de maio de 1973 (disponível em: https:/treaties.un.org/doc/Treaties/1977/02/19770203\%201135\%20PM/Ch_IX_01_dp.pdf. Acesso em: 05 set. 2020).
} 
contribuições obrigatórias ou avaliadas (assessed contributions), cujo inadimplemento pode acarretar a perda do direito de voto e a demais serviços que um Estado membro tenha direito. ${ }^{33}$ Seu valor, desde o biênio financeiro de 20042005, é calculado segundo a última escala utilizada pela ONU para quantificar suas contribuições, com cotas limite de no máximo $22 \%$ e de no mínimo $0.001 \%$ do total a ser custeado. ${ }^{34}$

A fórmula utilizada pela ONU, por sua vez, é revista a cada três anos, nos termos da Regra 160 do Regulamento da AGONU, com aconselhamento do Comitê de Contribuições. A mesma regra dispõe, na linha do artigo 17, (1), da Carta da ONU, ${ }^{35}$ que as cotas de cada país devem ser estabelecidas, de um modo geral, de acordo com a "capacidade de pagamento". ${ }^{36}$ Trata-se do princípio de mais comum utilização pelas organizações internacionais para quantificar suas contribuições compulsórias (AMERASINGHE, 2005, p. 359; SCHERMERS; BLOKKER, p. 660), na qual se prestigia o princípio da igualdade. A leitura do termo, no entanto, deve se aproximar mais da definição aristotélica (igualdade material, que consiste em tratar desigualmente os desiguais, na exata medida de sua desigualdade). Caso não houvesse respeito à capacidade de pagamento, poder-se-ia cogitar de ofensa ao princípio da igualdade soberana entre os Estados, posto que a desigualdade de contribuições conflitaria com a plena paridade de direitos a voto. Nesse contexto, um Estado estaria "pagando" mais pelo mesmo direito a voto que outro membro ao qual coubesse uma cota menor de contribuição (SCHERMERS; BLOKKER, p. 661). Por fim, também não se pode deixar de notar a semelhança do critério com o aspecto positivo do princípio da capacidade contributiva, ${ }^{37}$ norma de Direito Tributário que, no Brasil, está inscrita no artigo 145, § 1ํㅡㄹ CRFB.

Com a Resolução 73/271, de 22 de dezembro de 2018, a AGONU aprovou a escala de avaliação (scale of assessments) das cotas de contribuição relativas aos orçamentos de 2019-2021. A complexa fórmula leva em consideração os seguintes aspectos: $^{38}$ (a) estimativas de Produto Interno Bruto (PIB), calculadas a partir de

${ }^{33}$ Artigo $7^{\circ}$ da Constituição da OMS.

${ }^{34}$ Item 1 da Resolução WHA56.33 da AMS (OMS, 2003).

${ }^{35}$ Artigo 17, (2). As despesas da Organização serão custeadas pelos Membros, segundo cotas fixadas pela Assembléia Geral.

36 Rule 160. The Committee on Contributions shall advise the General Assembly concerning the apportionment, under Article 17, paragraph 2, of the Charter, of the expenses of the Organization among Members, broadly according to capacity to pay. The scale of assessments, when once fixed by the General Assembly, shall not be subject to a general revision for at least three years unless it is clear that there have been substantial changes in relative capacity to pay. The Committee shall also advise the General Assembly on the assessments to be fixed for new Members, on appeals by Members for a change of assessments and on the action to be taken with regard to the application of Article 19 of the Charter.

${ }_{37}$ Trata-se da obrigação de construir uma sociedade justa, com a distribuição equânime de direitos e deveres (CANOTILHO, 2003, p. 245).

${ }^{38}$ A explicitação integral da fórmula pode ser encontrada no relatório do Comitê de Contribuições apresentado na $73^{\underline{a}}$ sessão da AGONU (Documento A/73/11. Disponível em: https://undocs.org/A/73/11. Acesso em: 05/09/2020). 
uma média estatística de taxas de câmbio de mercado com base em períodos de $3 \mathrm{e}$ 6 anos; (c) ajustes para países com baixa ou média receita e significativa dívida externa; $(\mathrm{d})$ redução proporcional para países com renda per capita abaixo da média mundial; (e) cotas mínimas de $0.001 \%$; (f) cotas máximas de $0.01 \%$ para Países Menos Desenvolvidos ${ }^{39}$ e de $22 \%$ para o restante dos membros.

Dentro desse sistema, a AMS determinou ${ }^{40}$ que os EUA devem contribuir, no decorrer do biênio 2020-2021, com uma cota de 22\% da escala de contribuição, ou seja, o limite máximo, cujo valor bruto corresponde a USD 236.911.350,00. Ao Brasil, apenas para fins de comparação, registra-se que restou destinada a cota de 2,9482\%, equivalente ao valor bruto de USD 31.748.160,00. ${ }^{41}$ Apesar de as cifras serem elevadas, a verdade é que as contribuições obrigatórias ainda representam uma parcela relativamente pequena do orçamento da OMS.

O artigo 57 da Constituição da OMS prevê que a AMS ou o Conselho Executivo - esse último agindo em nome do primeiro - podem aceitar e administrar doações e legados destinados à organização, desde que estes não estejam sujeitos a condições incompatíveis com os fins e com a política da instituição. Trata-se, aqui, das contribuições voluntárias, de fundamental importância para o orçamento da OMS, as quais podem ser vertidas por Estados membros da organização, em complemento às suas contribuições obrigatórias, ou por entidades privadas. Tais prestações são divididas em: (i) contribuições voluntárias básicas (Core Voluntary Contributions $-(V C)$, que são feitas sem qualquer condição, tendo a OMS total discricionariedade na alocação de recursos dentro de suas atividades; (ii) contribuições para fundos temáticos e estratégicos (Thematic and Strategic Engagement funds), que, apesar de direcionadas a um fundo específico, apresentam um grau de flexibilidade parcial, ao permitir que a OMS utilize os recursos em atividades dentro da área temática em questão; e (iii) contribuições voluntárias específicas (Specified Voluntary Contributions), que são destinadas a áreas geográficas ou a programas específicos, e que devem ser utilizadas em um espaço de tempo pré-determinado. Essas últimas constituem a maioria das doações,

\footnotetext{
39 Os Países Menos Desenvolvidos (LDC, na sigla em inglês), são objetivamente definidos por decisão da AGONU desde 1971, quando a primeira listagem foi estabelecida pela Resolução 2768 (XXVI). Atualmente, a lista é composta pelos seguintes países: Afeganistão, Angola, Bangladesh, Benin, Butão, Burkina Faso, Burundi, Camboja, República Centro-Africana, Chade, Comores, Congo, Djibuti, Eritréia, Etiópia, Gâmbia, Guiné, Guiné-Bissau, Haiti, Kiribati, Laos, Lesoto, Libéria, Madagascar, Malawi, Mali, Mauritânia, Moçambique, Myanmar, Nepal, Níger, Ruanda, São Tomé e Príncipe, Senegal, Serra Leoa, Ilhas Salomão, Somália, Sudão do Sul, Sudão, Timor Leste, Togo, Tuvalu, Uganda, Tanzânia, Vanuatu, Iêmen e Zâmbia (Disponível em: https://www.un.org/development/desa/dpad/wpcontent/uploads/sites/45/publication/ldc_list.pdf. Acesso em: 05 set. 2020).

40 Resolução WHA72.12 da AMS, de 28 de maio de 2019.
}

41 A tabela com os valores indicados para cada país se encontra em: https://www.who.int/about/finances-accountability/funding/2020-21_AC_Summary.pdf. Acesso em 05 set. 2020. 
representando cerca de $90 \%$ dos recursos totais angariados mediante contribuições voluntárias. ${ }^{42}$

Para o biênio de 2020-2021, a OMS aprovou um orçamento total de USD 5.840.400.000,00 (cinco bilhões, oitocentos e quarenta milhões e quatrocentos mil), dos quais apenas USD 956.900.000,00 (novecentos e cinquenta e seis milhões e novecentos mil) serão provenientes de contribuições obrigatórias. O restante, USD 4.883.500.000,00 (quatro bilhões, oitocentos e oitenta e três milhões e quinhentos mil) virão de contribuições voluntárias. ${ }^{43}$

A forte dependência de contribuições voluntárias é, há algum tempo, motivo de preocupação para especialistas, em função do alegado risco de captura da instituição. Vaughan et al. (1996), contudo, já chegaram à conclusão de que o financiamento voluntário traz significativos benefícios para a OMS e, especialmente, para países de baixa renda. Além disso, conquanto haja evidência de que alguns doadores exercem considerável influência na organização, não se cogita de uma OMS "dirigida por doadores" (donor driven). Em suma, os benefícios do financiamento voluntário ultrapassariam os efeitos negativos trazidos pelo sistema.

Além disso, compartilha-se do entendimento exposto por FORTES (2020), segundo o qual a regulação global - principalmente no campo do Direito Sanitário Internacional - não é tão suscetível de captura, ${ }^{44}$ justamente em função do estabelecimento de um espaço regulatório complexo e fragmentado. Os riscos para a Governança Sanitária Global parecem advir, assim, não dos riscos de captura, mas de ruptura, conforme já analisado no capítulo anterior. Nas palavras de Fortes (2020, p. 230):

(...) a rede regulatória não está tão suscetível ao controle hegemônico de um único player poderoso, sendo constituída pela interação multilateral e dinâmica de múltiplos atores públicos e privados. Ademais, o espaço regulatório global está dotado de instrumentos e processos regulatórios para a difusão das regras de conduta decorrentes da regulação global. Além disso, o desenvolvimento do direito administrativo global estabeleceu uma série de mecanismos de participação, controle e de devido processo legal, de modo a ampliar a profissionalização dos organismos internacionais e a institucionalização da própria regulação global. Embora a análise dos regimes de incentivos e benefícios dos indivíduos responsáveis pela produção normativa e o tema da captura sejam relevantes, outros desafios para a regulação global

${ }^{42}$ Dados extraídos de https://www.who.int/about/planning-finance-and-accountability/how-whois-funded. Acesso em: 05 set. 2020.

43 Resolução WHA72.1, de 24 de maio de 2019. Disponível em: https://apps.who.int/gb/ebwha/pdf_files/WHA72/A72_R1-en.pdf. Acesso em: 05 set. 2020.

${ }^{44}$ Sobre os riscos de captura da regulação global, veja-se MATTLI; WOODS, 2009. 
advêm dos riscos da ruptura e da adaptação na aplicação concreta dos standards normativos.

Apesar disso, é evidente que o eventual abandono, pelos EUA, do financiamento obrigatório e voluntário da OMS resultaria em grandes problemas econômicos para a manutenção das atividades da organização. $\mathrm{O}$ gráfico a seguir apresenta os 20 maiores contribuidores para o orçamento da OMS no biênio 20182019:

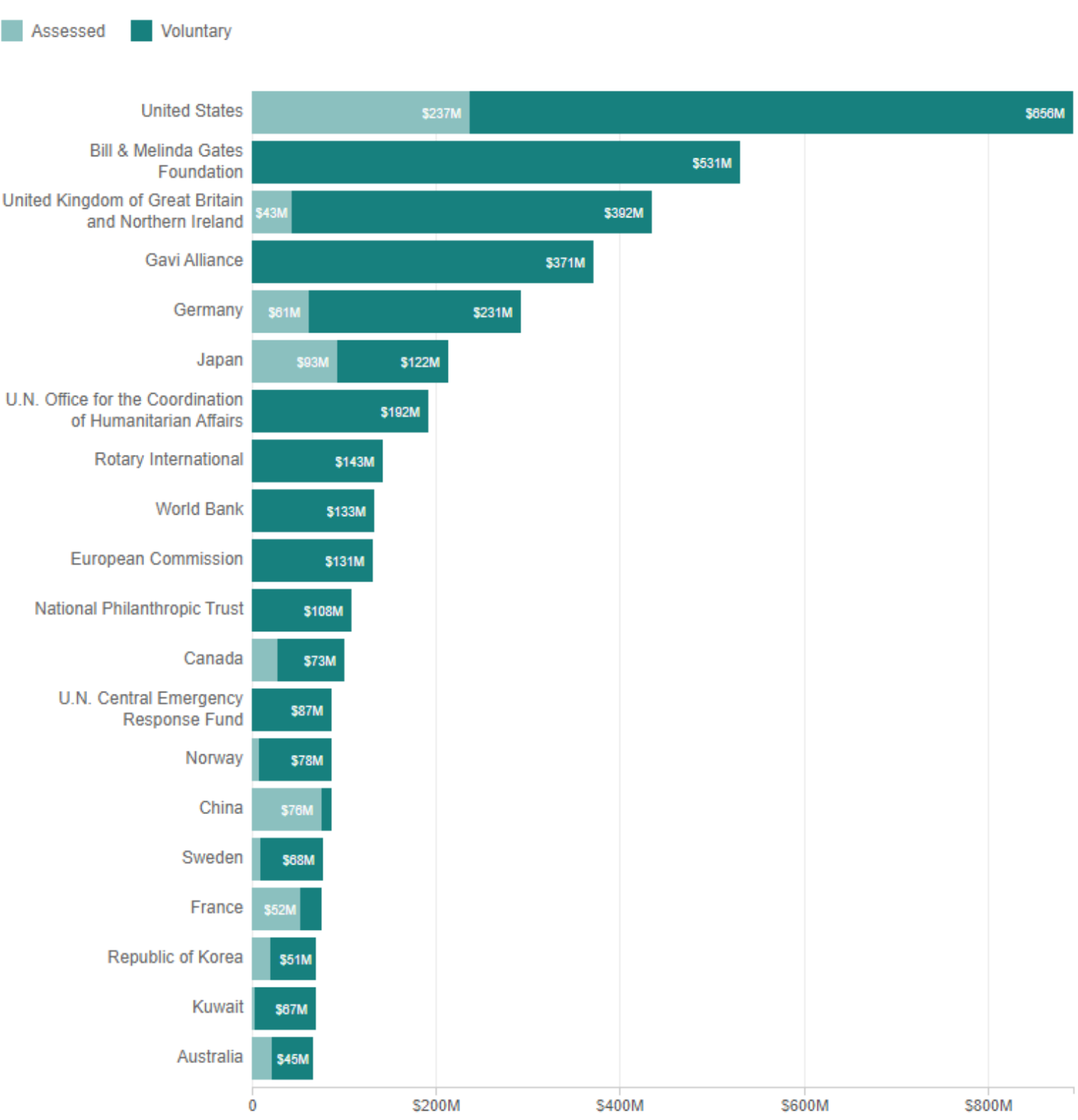

Figura 1 - Gráfico dos maiores contribuidores da OMS no biênio 2018-2019 Fonte: (HUANG, 2020) 
É possível identificar que os Estados Unidos, país com maior contribuição obrigatória na OMS, fornecem mais do que o dobro de seu financiamento compulsório em contribuições voluntárias, representando, ao total, parcela muito significativa do orçamento da organização. Daí se extrai a conclusão de que, de fato, o congelamento dos repasses norte-americano com certeza traria dificuldades financeiras para a organização.

Em outra perspectiva, é relevante ressaltar que, em segundo lugar, já surge a Fundação Bill \& Melinda Gates, entidade privada que contribuiu de forma unicamente voluntária com mais de 530 milhões de dólares.

Por fim, verifica-se que a OMS, acusada por Trump de ser uma "marionete da China" (BBC, 2020), recebeu do país asiático apenas pouco mais de 75 milhões de dólares no mesmo período, o que faz com que seja relativamente seguro afirmar que o risco de captura, se existente, certamente não depende de questões de financiamento.

\section{CONSIDERaÇões Finais}

O novo coronavírus trouxe desafios igualmente novos para diversas áreas do conhecimento humano, transformando profundamente as relações pessoais e o cotidiano. Sob a perspectiva do Direito não foi diferente: inúmeras são as questões jurídicas que se apresentam e que, provavelmente, produzirão mudanças estruturais que ainda se manifestarão com o decorrer do tempo.

No presente artigo, buscou-se abordar as principais questões relacionadas ao Direito Internacional Sanitário no contexto da pandemia de COVID-19. Em primeiro lugar, estabeleceu-se a existência de uma governança sanitária global na ordem internacional, composta de redes complexas de atores e normas, cujo ponto focal de coordenação é a OMS. No segundo capítulo, chegou-se à conclusão de que a organização produz diversas espécies normativas, de diferentes graus de vinculatividade. Defendeu-se que as recomendações para enfrentamento da pandemia, apesar de extrema relevância técnica, não são obrigatórias para os Estados membros, de modo que a ruptura com tal normatividade não representa ato ilícito internacional. Por fim, analisou-se o processo mais incisivo de ruptura ocorrido em 2020, representado pela tentativa de retirada dos EUA da Constituição da OMS e pelo anúncio de suspensão das contribuições destinadas ao organismo, condutas que, de fato, poderiam sinalizar problemas para a organização.

Registre-se, por fim, que a situação de incertezas e de instabilidades não deve ser encarada como a ruína da regulação global sanitária, mas apenas como mais um obstáculo superável, na busca do estabelecimento de uma sociedade internacional mais bem preparada para momentos de crise. De forma semelhante, os desafios aqui elencados não devem ser tidos como exemplos de ineficácia do Direito Internacional. Este, como foi visto, sequer pretende a coercibilidade de algumas de suas normas, de modo que, em verdade, a pandemia só poderia servir de exemplo e estudo de caso para o aprimoramento do sistema. 


\section{REFERÊNCIAS}

ACCIOLY, Hildebrando; SILVA, G. E. do Nascimento e; CASELLA, Paulo Borba. Manual de Direito Internacional Público. 24 ed. São Paulo: Saraiva Educação, 2019.

AGO, Roberto. Die internationalen Organisationen und ihre Funktionen in Inneren Tätigkeitsgebiet der Staaten. In: Rechtsfragen der Internationalem Organisation: Festschrift für Hans Wehberg zu seinem 70. Geburtstag. Frankfurt am Mein: Klosterman, 1958.

ALMEIDA, Paula Wojcikiewicz. O Direito Internacional frente à pandemia Covid-19: Quais são as possibilidades e os limites da atuação da OMS frente à pandemia Covid-19? JOTA, 09 abr. 2020. Disponível em:

https://www.jota.info/opiniao-e-analise/artigos/o-direito-internacional-frente-apandemia-covid-19-09042020. Acesso em: 05 set. 2020.

AMERASINGHE, Chittharanjan Felix. Principles of the Institutional Law of International Organizations. Second Edition. Cambridge: Cambridge University Press, 2005.

BBC. Coronavirus: Trump accuses WHO of being a "puppet of China". 19 mai. 2020. Disponível em: https://www.bbc.com/news/health-52679329. Acesso em: 05 set. 2020.

CHAZOURNES, Boisson de. Le pouvoir réglementaire de l'Organisation mondiale de la santé à l'aune de la santé mondiale: réflexions sur la portée et la nature du Règlement sanitaire international de 2005. In: Droit du pouvoir, pouvoir du droit: mélanges offerts à Jean Salmon. Bruxelles: Bruylant, 2007, p. 1157-1181.

CIJ. Accordance with International Law of the Unilateral Declaration of Independence in Respect of Kosovo, Advisory Opinion, I.C.J. Reports, 2010, p. 403.

Armed Activities on the Territory of the Congo (New Application: 2002) (Democratic Republic of the Congo v. Rwanda), Jurisdiction and Admissibility, Judgment. I.C.J. Reports, 2006, p. 6. 
DALTON, Robert E. et al. The Vienna Convention on the Law of Treaties: Consequences for the United States. Proceedings of the Annual Meeting (American Society of International Law). Vol. 78 (april 12-14, 1984), p. 276-284.

FIDLER, David P.; GOSTIN, Lawrence O. The New International Health Regulations: An Historic Development for International Law and Public Health. The Journal of Law, Medicine \& Ethics, 34(1), p. 85-94.

FORTES, Pedro Rubim Borges. A Regulação Global para Combate à COVID-19: Riscos de captura, ruptura e adaptação. Passagens. Revista Internacional de História Política e Cultura Jurídica. Rio de Janeiro: vol. 12, n. 2, maio-agosto, 2020, p. 221-242.

EUA. Casa Branca. Remarks by President Trump in Press Briefing. 14 abr. 2020. Disponível em: https://www.whitehouse.gov/briefings-statements/remarkspresident-trump-press-briefing/. Acesso em: 04 set. 2020.

G1. Trump anuncia que iniciou retirada formal dos EUA da OMS. 07 abr. 2020. Disponível em: https://g1.globo.com/mundo/noticia/2020/07/07/trump-vai-retirarformalmente-os-eua-da-oms-diz-agencia.ghtml. Acesso em: 04 set. 2020.

G1. Biden anuncia retorno dos EUA ao Acordo de Paris e à OMS e quais medidas de Trump serão anuladas. 20 jan. 2021. Disponível em: https:/g1.globo.com/mundo/noticia/2021/01/20/biden-anuncia-retorno-dos-eua-aoms-e-ao-acordo-de-paris-e-medidas-de-trump-que-serao-revistas.ghtml. Acesso em 09 abr. 2021.

GOSTIN, Lawrence O.; SRIDHAR, Devi; HOUGENDOBLER, Daniel. The normative authority of the World Health Organization. Public Health, XXX (2015), Governance for Health Special Issue Paper, p. 1-15.

HUANG, Pien. Trump And WHO: How Much Does The U.S. Give? What's The Impact Of A Halt In Funding? NPR, 2020. Disponível em:

https://www.npr.org/sections/goatsandsoda/2020/04/15/834666123/trump-andwho-how-much-does-the-u-s-give-whats-the-impact-of-a-halt-in-funding. Acesso em: 05 set. 2020 .

KEOHANE, Robert O. MARTIN, Lisa L. The Promise os Institutionalist Theory. International Security, Vol. 20, No. 1 (Summer, 1995), p. 39-51. 
MATTLI, Walter; WOODS, Ngaire (Org.). In whose benefit? Explaining regulatory change in global politics. In: The politics of global regulation. New Jersey: Princeton University Press, 2009. p. 1-43.

MAZZUOLI, Valerio de Oliveira. As determinações da OMS são vinculantes ao Brasil? Gen Jurídico, 30 mar. 2020. Disponível em:

http://genjuridico.com.br/2020/03/30/determinacoes-da-oms-vinculantes-brasil/. Acesso em: 05 set. 2020.

. Direito dos tratados. 2. ed. rev., atual. e ampl. Rio de Janeiro: Forense, 2014.

. Responsabilidade Internacional dos Estados por Epidemias e Pandemias Transnacionais: o caso da COVID-19 provinda da República Popular da China. Revista de Direito Civil Contemporâneo, n. ํㅡㄹ, abr./jun. 2020.

MENUCCI, Daniel Lins. O Regulamento Sanitário Internacional (2005) e a Vigilância em Saúde. Revista de Direito Sanitário, vol. 7, n. 1/2/3, 2006, p. 54-87.

MONDIELLI, E. Breves considerações sobre as especificidades das normas sanitárias internacionais de forma geral e em particular do regulamento sanitário internacional. Revista de Direito Sanitário, vol. 8, n. 1, mar./jun. 2007, p. 118-150.

OLIVEIRA, Pedro Farias. O impacto do acordo de Paris na governança ambiental global. In: Marilda Rosado de Sá Ribeiro (org.). Governança Global. v.1. Belo Horizonte: Arraes Editores, 2017, p. 230-248.

OMS. Assembleia Mundial da Saúde. Resolução WHA56.33. 28 mai. 2003. Disponível em: https://apps.who.int/gb/archive/pdf_files/WHA56/ea56r33.pdf. Acesso em 05 set. 2020.

ONU. Coleção de Tratados: status da Constituição da Organização Mundial da Saúde. 09 abr. 2020. 2020a. Disponível em

https://treaties.un.org/Pages/ViewDetails.aspx?src=TREATY\&mtdsg_no=IX1\&chapter=9\&clang=_en. Acesso em: 05 set. 2020.

\section{Coleção de Tratados: status da Convenção de Viena sobre Direito dos}

Tratados. 09 abr. 2020. 2020b. Disponível em:

https://treaties.un.org/Pages/ViewDetailsIII.aspx?src=TREATY\&mtdsg_no=XXIII$1 \&$ chapter=23\&Temp=mtdsg3\&clang=_en. Acesso em: 04 set. 2020. 
. Note to Correspondents in answer to questions regarding the World Health Organization. 07 jul. 2020. 2020c. Disponível em:

https://www.un.org/sg/en/content/sg/note-correspondents/2020-07-07/notecorrespondents-answer-questions-regarding-the-world-health-organization. Acesso em: 04 set. 2020.

REZEK, Francisco. Direito internacional público: curso elementar. 17. ed. São Paulo: Saraiva, 2018.

RUGGIE, John Gerard. Global Governance and "New Governance Theory": Lessons from Business and Human Rights. Global Governance, 20 (2014), p. 5-17.

SCHERMERS, Henry G.; BLOKKER, Niels M. International Institutional Law: Unity within Diversity. Sixth Revised Edition. Leiden, Boston: Brill Nijhoff, 2018.

SHARP, Walter R. The new World Health Organization. The American Journal of International Law. Volume 41, Issue 3, july 1947, p. 509-530.

SOARES, Guido F. S. O Direito Internacional Sanitário e seus Temas:

Apresentação de sua Incômoda Vizinhança. Revista de Direito Sanitário, vol. 1, n. 1, novembro de 2000, p. 49-88.

SOUZA, Rafael Soares. Qual o valor jurídico das recomendações da Organização Mundial da Saúde? Consultor Jurídico, 14 abr. 2020. Disponível em: https://www.conjur.com.br/2020-abr-14/opiniao-qual-valor-juridicorecomendacoes-oms\#_ftn9. Acesso em: 05 set. 2020.

SPAGNOLO, Andrea. (Non) Compliance with the International Health Regulations of the WHO from the Perspective of the Law of International Responsibility. Global Jurist. Volume 18, issue 1, abr. 2018.

THALER, Richard H. Misbehaving: The Making of Behavioral Economics. New York, London: W. W. Norton \& Company, 2015.

VASCONCELOS, Raphael Carvalho de. Direito internacional, eficácia e efetividade. Revista Interdisciplinar de Direito da Faculdade de Direito de Valença, v. 16, n. 2, jul./dez. 2018, p. 271-298. 
VAUGHAN, J. Patrick et al. WHO and the effects of extrabudgetary funds: is the Organization donor driven? Health Policy and Planning, 11 (3). Oxford: Oxford University Press, p. 253-264.

VIRZO, Roberto. The Proliferation of Institutional Acts of International Organizations: A Proposal for Their Classification. In: VIRZO, Roberto; INGRAVALLO, Ivan (eds.). Legal Aspects of International Organizations, vol. 54. Leiden, Boston: Brill Nijhoff, 2015, p. 293-323.

VITTA, Cino. Droit Sanitaire International. In: Recueil des Cours de l'Académie de Droit International de La Haye, vol. 33, 1933, p. 546/667. 